\title{
Procalcitonin for diagnosis of infection and guide to antibiotic decisions: past, present and future
}

\author{
Philipp Schuetz ${ }^{1 *}$, Werner Albrich ${ }^{2}$ and Beat Mueller ${ }^{2}$
}

\begin{abstract}
There are a number of limitations to using conventional diagnostic markers for patients with clinical suspicion of infection. As a consequence, unnecessary and prolonged exposure to antimicrobial agents adversely affect patient outcomes, while inappropriate antibiotic therapy increases antibiotic resistance. A growing body of evidence supports the use of procalcitonin (PCT) to improve diagnosis of bacterial infections and to guide antibiotic therapy. For patients with upper and lower respiratory tract infection, post-operative infections and for severe sepsis patients in the intensive care unit, randomizedcontrolled trials have shown a benefit of using PCT algorithms to guide decisions about initiation and/or discontinuation of antibiotic therapy. For some other types of infections, observational studies have shown promising first results, but further intervention studies are needed before use of PCT in clinical routine can be recommended. The aim of this review is to summarize the current evidence for PCT in different infections and clinical settings, and discuss the reliability of this marker when used with validated diagnostic algorithms.
\end{abstract}

\section{Background}

Emerging bacterial resistance to antimicrobial therapeutics calls for more stringent efforts to reduce antibiotic overuse [1]. Towards this aim, there has been considerable interest in antibiotic stewardship programs aimed at reducing antibiotic overuse by tailoring antibiotic therapy to individual needs of patients [2,3]. Despite the successful implementation of diagnostic biomarkers in different fields of medicine (for example, D-dimers in pulmonary embolism, natriuretic peptides in acute heart

\footnotetext{
* Correspondence: Philipp.Schuetz@post.harvard.edu

'Harvard School of Public Health, 667 Huntington Ave, 02115 Boston (MA), USA

Full list of author information is available at the end of the article
}

failure, troponin in myocardial infarction), accurate and timely diagnosis of bacterial infections remains a challenge $[4,5]$. Reliable clinical and/or microbiological parameters from easy to obtain specimens that may be used to diagnose bacterial infections and rule out other infections not in need of antibiotic therapy have been largely lacking. The main disadvantages of many current microbiological methods are diagnostic delays (for example, culture methods), suboptimal sensitivity (for example, blood cultures) and low specificity due to contamination (for example, sputum cultures), whereas others are not amenable to routine diagnostics due to their invasive nature (for example, lung biopsy). Inflammatory markers, such as C-reactive protein (CRP) or white blood cells (WBC), lack specificity for bacterial infections [6]. This is partly explained by the heterogeneity of different infections and the complex interaction of different proand anti-inflammatory mediators of the host response aimed at combating invading pathogens during systemic infections, which depend on timing, type, extent and site of the underlying infection.

In this diagnostic dilemma, procalcitonin (PCT) has stimulated great interest as a potentially more specific marker for bacterial infection. PCT is produced ubiquitously in response to endotoxin or mediators released in response to bacterial infections (that is, interleukin (IL)$1 \beta$, tumor necrosis factor (TNF)- $\alpha$, and IL-6) and strongly correlates with extent and severity of bacterial infections [7]. Because up-regulation of PCT is attenuated by interferon (INF)- $\gamma$, a cytokine released in response to viral infections, $\mathrm{PCT}$ is more specific for bacterial infections and may help to distinguish bacterial infections from viral illnesses [8-11]. PCT shows a favorable kinetic profile for use as a clinical marker: it promptly increases within 6 to 12 hours upon stimulation and circulating PCT levels halve daily when the infection is controlled by the host immune system or antibiotic therapy [12]. PCT correlates with bacterial load [13-15] and severity of infection [6,16-18]. PCT thus has prognostic implications and the course of PCT 
predicts fatal outcome in patients with communityacquired pneumonia (CAP) [18-21] and critically ill patients with sepsis [22].

Based on this evidence, PCT has been put forward as a promising candidate marker for diagnosis and for antibiotic stewardship in patients with systemic infections [23]. Importantly, as with any diagnostic tool, PCT should be used embedded in clinical algorithms adapted to the type of infection and the clinical context and setting. While for some types of infections and clinical settings optimal PCT cut-offs have been established and their safety and efficacy shown in randomized-controlled intervention trials, for other types of infection only observational studies are available today (Figure 1), and thus the clinical benefit and safety of using PCT remains undefined.

The aim of this review is to summarize the current evidence for PCT in different infections and clinical settings, and discuss the strengths and limitations of PCT, and the reliability of this marker when used with validated diagnostic algorithms.

\section{Procalcitonin as a diagnostic marker: results from observational studies}

A plethora of observational studies have investigated the diagnostic potential of PCT in different clinical situations and different types and sites of infections. Table 1 summarizes study designs, proposed PCT cut-offs and main conclusions of selected relevant studies investigating different types of infections. This selection focuses on more recent research and on studies using highly sensitive PCT assays (that is, with a functional assay sensitivity around $0.06 \mu \mathrm{g} / \mathrm{L})[24,25]$.

For the diagnosis of blood stream infections and bacteremia, studies found a high diagnostic performance of PCT [13-15]. To distinguish blood contamination from true blood stream infection in patients with growth of coagulase-negative staphylococci in their blood cultures,

\section{Observational studies}

Intervention studies

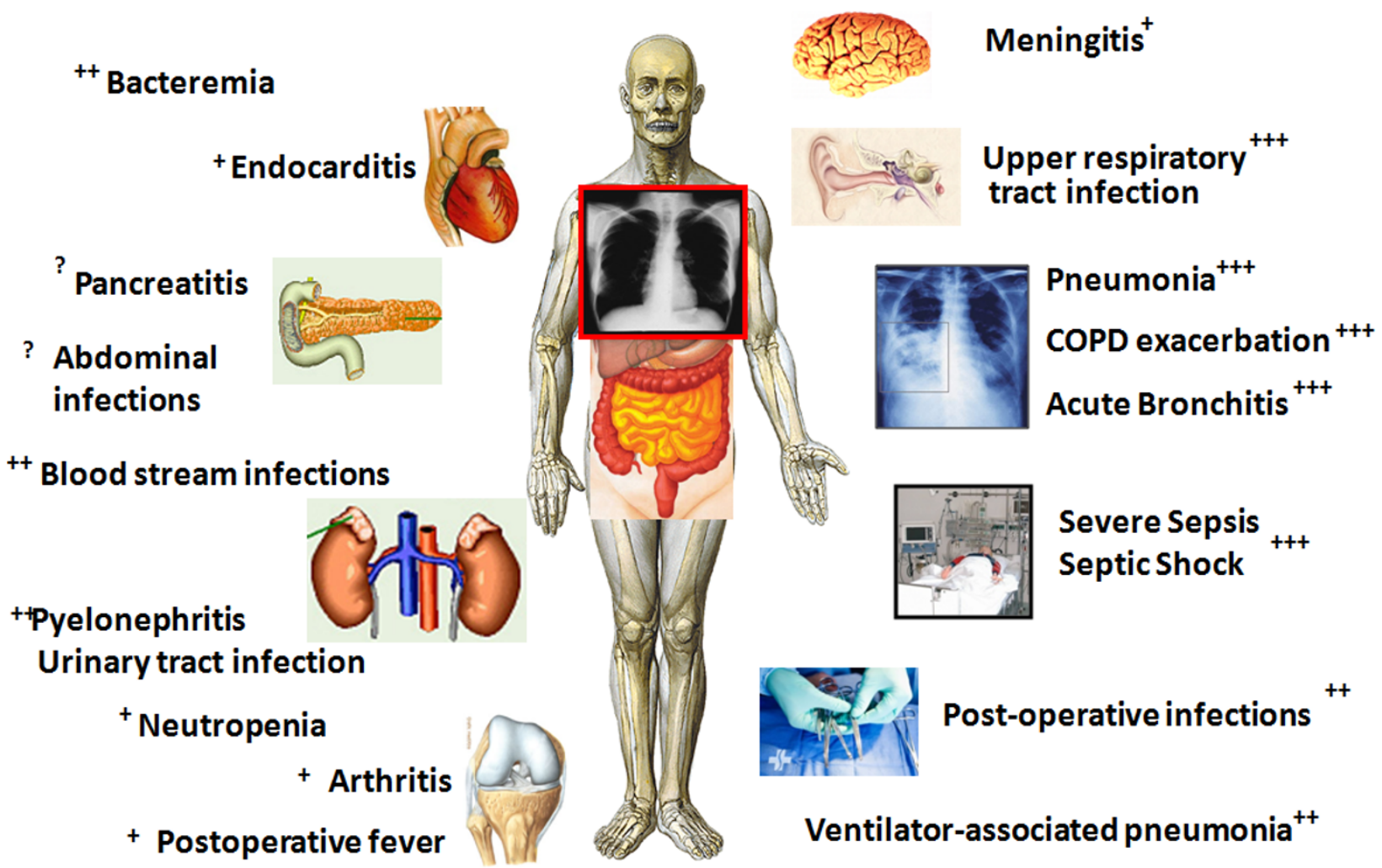

Figure 1 Available evidence concerning PCT in different infections derived from observational and randomized-controlled intervention studies. While for some infections, intervention studies have investigated benefit and harm of using PCT for antibiotic decisions (right side), for other infections only results from diagnostic (observation) studies are available with mixed results (left side). Abbreviations: PCT, procalcitonin. + moderate evidence in favor of $\mathrm{PCT} ;++$ good evidence in favor of $\mathrm{PCT} ;+++$ strong evidence in favor of $\mathrm{PCT}$; ? evidence in favor or against the use of PCT still undefined 
Table 1 Overview of studies investigating the use of PCT in different types and sites of infection

\begin{tabular}{|c|c|c|c|c|c|}
\hline Type of infection & $\begin{array}{c}\text { Study } \\
\text { designs }\end{array}$ & $\begin{array}{l}\text { PCT cut-off } \\
\text { (ug/L) }\end{array}$ & $\begin{array}{l}\text { Benefit of } \\
\text { using PCT? }\end{array}$ & Main conclusions & $\begin{array}{r}\text { Selected } \\
\text { References } \\
\end{array}$ \\
\hline Abdominal Infections & observational & 0.25 & $?$ & $\begin{array}{c}\text { PCT may help to exclude ischemia and necrosis in bowel } \\
\text { obstruction }\end{array}$ & {$[29-32]$} \\
\hline Arthritis & observational & $0.1-0.25$ & + & $\begin{array}{c}\text { PCT differentiates non-infectious (gout) arthritis from true } \\
\text { infection }\end{array}$ & {$[37,38,73]$} \\
\hline Bacteremic infections & observational & 0.25 & ++ & Low PCT levels help to rule out bacteremic infections & {$[14,15,74]$} \\
\hline $\begin{array}{l}\text { Blood stream infection } \\
\text { (primary) }\end{array}$ & observational & 0.1 & ++ & PCT differentiates contamination from true infection & [13] \\
\hline Bronchitis & RCT & $0.1-0.5$ & +++ & $\begin{array}{c}\mathrm{PCT} \text { reduces antibiotic exposure in the ED without adverse } \\
\text { outcomes }\end{array}$ & {$[50,52]$} \\
\hline COPD exacerbation & RCT & $0.1-0.5$ & +++ & $\begin{array}{c}\text { PCT reduces antibiotic exposure in the ED and hospital } \\
\text { without adverse outcomes }\end{array}$ & [50-52] \\
\hline Endocarditis & observational & 2.3 & + & $\begin{array}{c}\mathrm{PCT} \text { is an independent predictor for acute endocarditis } \\
\text { with high diagnostic accuracy }\end{array}$ & {$[27,28]$} \\
\hline Meningitis & before-after & 0.5 & + & $\begin{array}{c}\mathrm{PCT} \text { reduces antibiotic exposure during outbreak of viral } \\
\text { meningitis }\end{array}$ & {$[75-77]$} \\
\hline Neutropenia & observational & $0.1-0.5$ & + & $\begin{array}{c}\text { PCT is helpful at identifying neutropenic patients with } \\
\text { systemic bacterial infection }\end{array}$ & [39-41] \\
\hline Pancreatitis & observational & $0.25-0.5$ & $?$ & $\begin{array}{l}\text { PCT correlates with severity and extend of infected } \\
\text { pancreatitis }\end{array}$ & {$[33,36]$} \\
\hline Pneumonia & RCT & $\begin{array}{l}0.1-0.5 ; 80- \\
90 \% \downarrow\end{array}$ & +++ & $\begin{array}{c}\text { PCT reduces antibiotic exposure in the hospital without } \\
\text { adverse outcomes }\end{array}$ & {$[16,50,52-55]$} \\
\hline Postoperative fever & observational & $0.1-0.5$ & + & $\begin{array}{c}\text { PCT differentiates non-infectious fever from post-operative } \\
\text { infections }\end{array}$ & [78] \\
\hline $\begin{array}{l}\text { Postoperative } \\
\text { Infections }\end{array}$ & $\mathrm{RCT}$ & $\begin{array}{l}0.5-1.0 ; 75- \\
85 \% \downarrow\end{array}$ & ++ & $\begin{array}{l}\mathrm{PCT} \text { reduces antibiotic exposure in the surgical ICU without } \\
\text { adverse outcomes }\end{array}$ & {$[64,65]$} \\
\hline Severe sepsis/Shock & RCT & $\begin{array}{l}0.25-0.5 ; 80- \\
\quad 90 \% \downarrow\end{array}$ & +++ & $\begin{array}{c}P C T \text { reduces antibiotic exposure in the } I C U \text { without adverse } \\
\text { outcomes }\end{array}$ & {$[61,62]$} \\
\hline $\begin{array}{l}\text { Upper respiratory tract } \\
\text { infections }\end{array}$ & $\mathrm{RCT}$ & $0.1-0.25$ & ++ & $\begin{array}{l}\mathrm{PCT} \text { reduces antibiotic exposure in primary care without } \\
\text { adverse outcomes }\end{array}$ & {$[5$} \\
\hline Urinary tract infections & observational & 0.25 & + & PCT correlates with severity of urinary tract infections & {$[15,26]$} \\
\hline $\begin{array}{l}\text { Ventilator-associated } \\
\text { pneumonia }\end{array}$ & $\mathrm{RCT}$ & $0.1-0.25$ & ++ & PCT reduces antibiotic exposure without adverse outcomes & {$[62,63]$} \\
\hline
\end{tabular}

Abbreviations: COPD, chronic obstructive pulmonary disease; ED, Emergency department; PCT, procalcitonin; RCT, randomized-controlled trial. The level of evidence in favor or against PCT for each infection was rated by two of the coauthors (PS, WCA) independently and disagreements were resolved by consensus. + moderate evidence in favor of PCT; ++ good evidence in favor of PCT; +++ strong evidence in favor of PCT; ? evidence in favor or against the use of PCT still undefined

PCT demonstrated a better discriminatory ability compared to WBC and CRP [13]. At a cut-off of $0.1 \mathrm{ug} / \mathrm{L}$, PCT had a very high sensitivity to exclude true infection. Two other studies, focused on the use of PCT to predict bacteremia infections in patients with CAP [14] and urinary tract infections (UTI) [15]. A PCT cut off of $0.25 \mathrm{ug} / \mathrm{L}$ was most helpful to exclude bacteremic disease with a high negative predictive value in both settings.

In UTIs, evidence for the utility of PCT comes primarily from the pediatric literature, where it has a similar sensitivity but superior specificity compared to CRP for the prediction of pyelonephritis in children with febrile UTIs [26]. It correlates with the extent of renal involvement and with renal scarring. Similarly, in patients with infectious endocarditis, circulating PCT levels were elevated compared to non-infected patients in two independent studies $[27,28]$. Unfortunately, a reliable PCT threshold for diagnosing or excluding infective endocarditis was neither proposed nor tested in intervention studies. Importantly, subacute forms of endocarditis or prosthetic-valve endocarditis may show different characteristics compared to acute forms due to their low inflammatory nature and possibly biofilm production.

Few studies have investigated the use of PCT in intraabdominal infections [29-36]. While PCT showed promise as a marker to exclude perforation and ischemia in obstructive bowel syndrome [32], the utility in acute appendicitis [31] and pancreatitis [33,36] was limited and PCT was more helpful as a prognostic marker for severe disease and adverse outcome. While localized infections may not induce a massive PCT up-regulation, studies found PCT of diagnostic utility in patients with 
arthritis [37] and osteomyelitis [38], particularly when subtle increases and a low PCT cut off $(0.1 \mathrm{ug} / \mathrm{L})$ were considered.

Different studies have evaluated the utility of PCT in patients with febrile neutropenia [39-41]. A recent systematic review found 30 articles on the topic and concluded that PCT has value as a diagnostic and prognostic tool in patients with febrile neutropenia, but that due to differences in patient populations and study qualities, further research is needed [40]. Importantly in this regard, the production of PCT seems not to be attenuated by corticosteroids $[42,43]$ and PCT production does not rely on white blood cells [44-46]. A study including 102 critically ill patients with systemic infections in a medical intensive care unit (ICU) found significantly lower CRP and IL-6 levels, but similar PCT levels, in patients treated with systemic corticosteroids (20 to $1500 \mathrm{mg} /$ day of prednisone parenterally) compared to untreated patients[42]. These observations were confirmed in healthy male volunteers who received different doses of prednisolone up to $30 \mathrm{mg}$ before a sepsis-like syndrome was induced with Escherichia coli lipopolysaccharide (LPS) injections[43]. While other biomarkers were significantly inhibited in a dose-dependent way, levels of PCT showed no inhibition within the study period. Whether this is also true for other corticosteroid doses, however, remains unknown. The value of PCT in febrile neutropenia may be as part of a combination with other biomarkers of bacterial infection such as IL- 6 and IL- 8 as shown in a small study of pediatric patients with febrile neutropenia [39].

\section{Procalcitonin as a guide for antibiotic decisions: results from randomized-controlled studies}

The clinical implications of the above mentioned observational studies may be limited by differences in disease definitions and patient groups, use of insensitive (semiquantitative) PCT assays, and different methodological issues such as observer bias, selection bias and issues of sample availability, co-infection and colonization. To overcome these limitations, several randomized-controlled studies have investigated the use of PCT to assist in decisions about initiation and/or duration of antibiotic therapy (antibiotic stewardship). Thereby the benefit of PCT was measured by clinical outcomes, assuming that if the patient recovers without antibiotics, there was no relevant bacterial illness in need of antibiotic therapy. Importantly, all intervention studies used fully automated highly sensitive PCT assays, the results of which can be obtained in the clinical routine of an emergency department within one hour thus permitting bed-side decision making. Recently, different options for PCT testing have become available, including the KRYPTOR [25], the VIDAS system (Biomerieux) [47], the Liaison
BRAHMS PCT (DiaSorin)[48] and the Elecsys BRAHMS PCT (Roche Diagnostics) [49].

All published studies on antibiotic stewardship used similar clinical algorithms with recommendations for or against antibiotic treatment based on PCT cut-off ranges. For moderate risk patients with respiratory tract infections in the emergency department (Figure 2), algorithms recommended initiation and discontinuation of antibiotic therapy based on four different cut-off ranges. Initial antibiotics were withheld mostly in patients with low risk for systemic infection with acute bronchitis or exacerbation of chronic obstructive pulmonary disease [ECOPD]). Clinical re-evaluation and a repeated measurement of PCT were recommended after 6 to 24 hours if the clinical condition did not improve spontaneously. If PCT values were increased and antibiotic therapy was initiated, repeated PCT measurements were recommended every one to two days, depending on the clinical severity of disease, and antibiotics were discontinued using the same cut off ranges or a marked drop by $80 \%$ to $90 \%$ if initial levels were high (for example $>5$ $\mu \mathrm{g} / \mathrm{l})$. To assure safety, specific criteria were predefined where this algorithm could be overruled, such as lifethreatening disease or immediate need for ICU admission. For high risk patients in the ICU setting (Figure 3), algorithms focused on discontinuation of antibiotic therapy if a patient showed a clinical recovery and PCT levels decreased to 'normal' levels, or by at least $80 \%$ to $90 \%$.

The first intervention study testing PCT as a guide for antibiotic decisions included patients with different types and severities of respiratory infections [50]. Clinical outcomes for both groups were similar, but the PCT-guided group had markedly lower rates of antibiotic prescriptions (44\% versus $83 \%$ ), particularly in patients with ECOPD and acute bronchitis. Two subsequent trials evaluated the effect of PCT guidance for antibiotic discontinuation in CAP and ECOPD. PCT guidance reduced the duration of antibiotic therapy by $65 \%$ in CAP patients [16] and the prescription of antibiotics from $72 \%$ to $40 \%$ in ECOPD patients [51]. A subsequent multicenter trial [52] confirmed earlier results and found a reduction of antibiotics by $32 \%$ in CAP, by $50 \%$ in ECOPD and by $65 \%$ in acute bronchitis. Again, antibiotic exposure in ECOPD and acute bronchitis decreased mainly by not initiating treatment at all, whereas for CAP it was principally from reduction in duration of therapy. Importantly, the overall rate of adverse events was similar in both study arms and excluded a risk of more than $0.4 \%$ for PCT guided patients. Interestingly, patients with bacteremia CAP had markedly increased PCT concentrations resulting in longer treatment duration compared to culture-negative CAP patients with a lower infection-related risk [17]. 


\section{PCT algorithm for patients with respiratory tract infection}

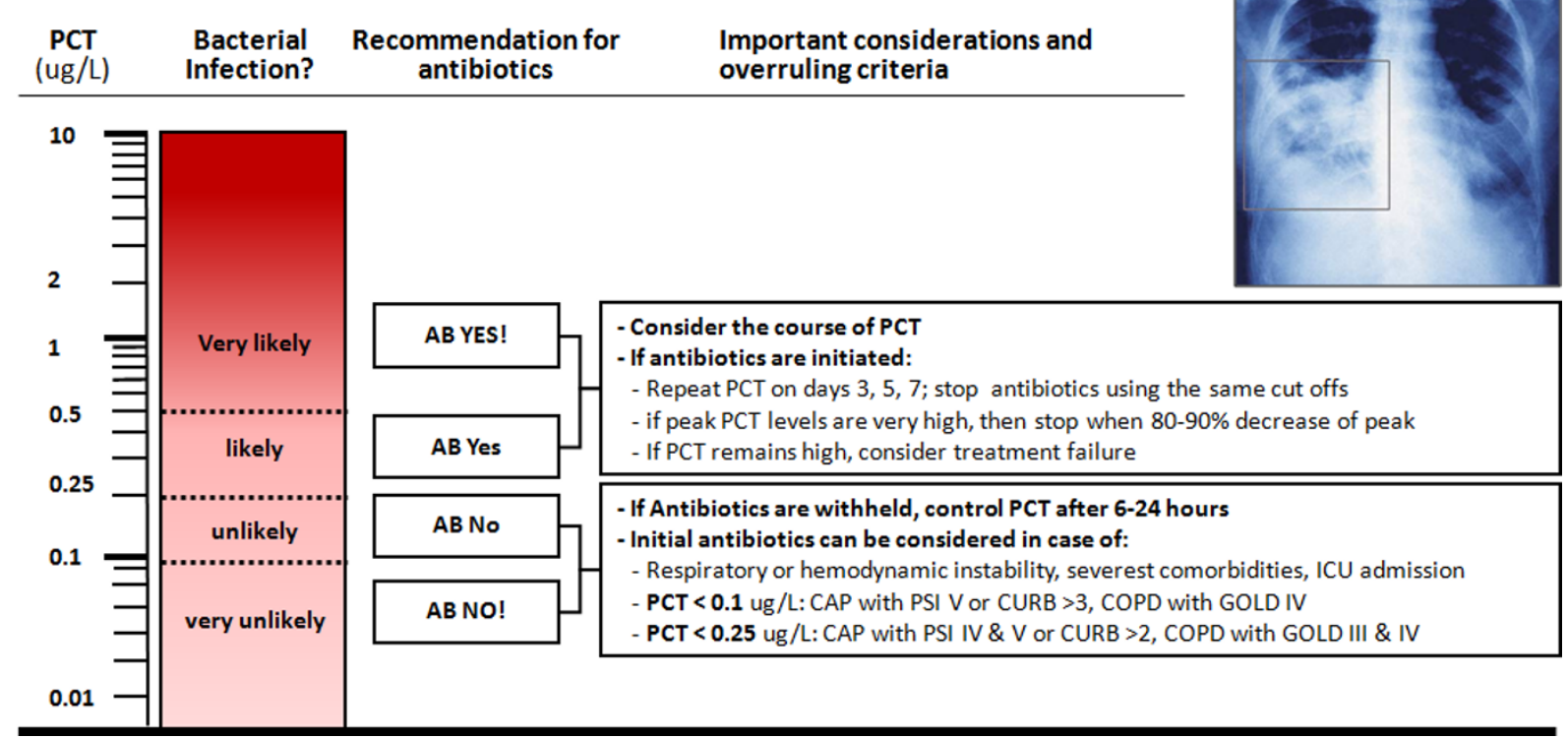

Figure 2 PCT algorithm in patients with respiratory tract infections in the Emergency Department. The clinical algorithm for antibiotic stewardship in patients with respiratory tract infections in the Emergency Department encourages $(>0.5 \mu \mathrm{g} / \mathrm{l}$ or $>0.25 \mu \mathrm{g} / \mathrm{l})$ or discourages $(<0.1$ $\mu \mathrm{g} / \mathrm{l}$ or $<0.25 \mu \mathrm{g} / \mathrm{l})$ initiation or continuation of antibiotic therapy more or less based on PCT specific cut-off ranges. Abbreviations: AB, antibiotic; LRTI, lower respiratory tract infection; PCT, procalcitonin; PSI, Pneumonia Severity Score.

\section{PCT algorithm for stopping antibiotics in patients with sepsis in the ICU}

\begin{tabular}{cccc}
$\begin{array}{c}\text { PCT } \\
\text { (ug/L) }\end{array}$ & $\begin{array}{c}\text { Ongoing } \\
\text { infection? }\end{array}$ & $\begin{array}{c}\text { Recommendation for } \\
\text { stopping antibiotics }\end{array}$ & Important considerations \\
\hline
\end{tabular}

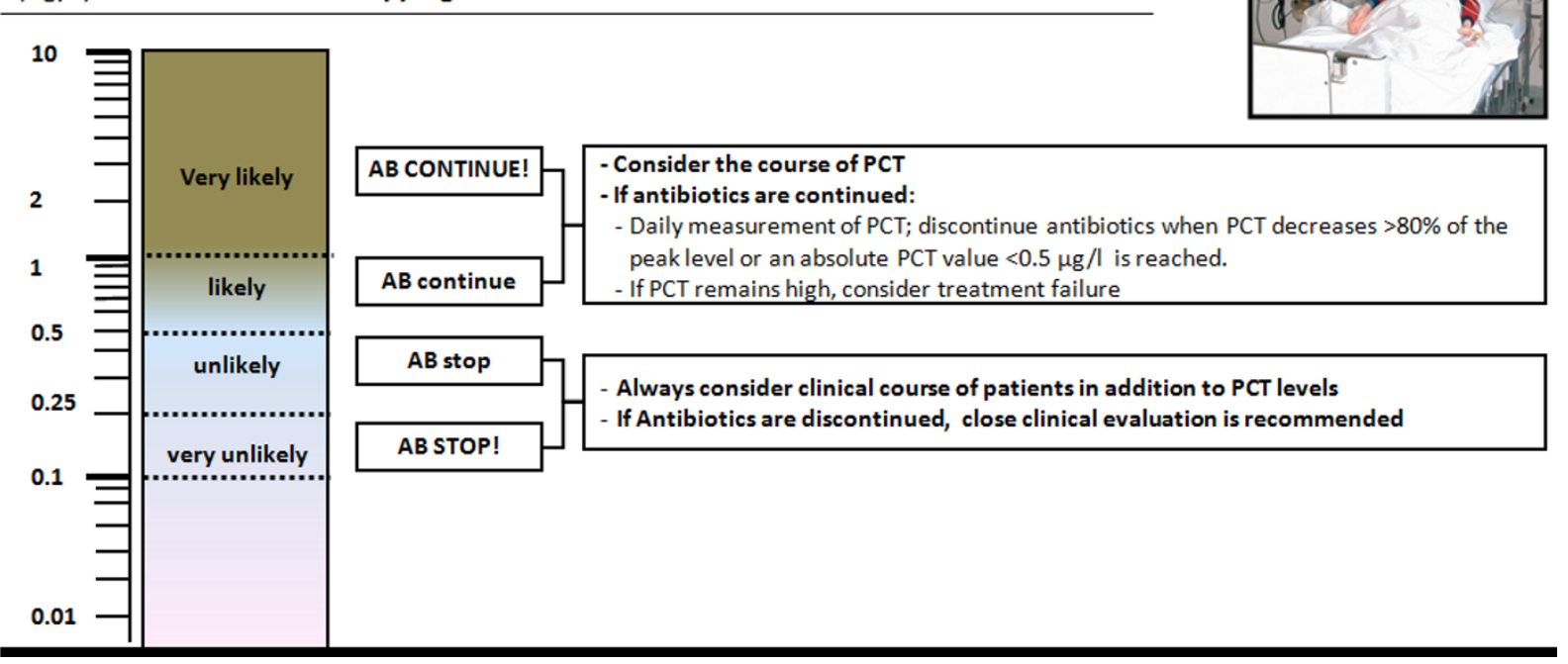

Figure 3 PCT algorithm in patients with sepsis in the ICU. In critically ill patients in the ICU, cut-offs are higher and initial empiric antibiotic therapy should be encouraged in all patients with suspicion of sepsis. PCT cut-offs are helpful in the subsequent days after admission to shorten the courses of antibiotic therapy in patients with clinical improvement. Abbreviations: $A B$, antibiotic; $P C T$, procalcitonin. 
Similar results in patients with respiratory infections were also reported in trials from Denmark [53] and China [54,55], and recently from an observational 'real life'- quality control survey in Switzerland [56].

Arguably, the most important (over-) use of antibiotics occurs in primary care. As many as $75 \%$ of patients with upper and lower respiratory infections receive antibiotics, despite the mostly viral origin of the condition [57]. Two multicenter primary care trials, powered for noninferiority of clinical outcomes, investigated the safety and feasibility of PCT guided algorithms in patients with upper and lower respiratory infections, essentially relying on an initial PCT measurement only [58-60]. Both trials found substantial reductions in antibiotic exposure (by $75 \%$ and $42 \%$ ), and similar clinical outcomes, particularly a similar time to recovery.

In more high risk patients in the ICU setting, different trials have investigated the use of PCT, mainly for discontinuation of antibiotics. The first small proof of concept study [61] found a four-day reduction in the duration of antibiotic therapy in patients with severe sepsis, but only in the per protocol analysis. A subsequent large multicenter trial in France recently validated this concept in more than 600 patients [62]. PCT guided patients had similar 30-day mortality rates and similar rates of relapses, but markedly more antibiotic-free days alive (14.3 versus 11.6). Another multinational ICU study focused on ventilator-associated pneumonia and found that PCT guidance resulted in a higher number of antibiotic free-days alive (13 versus 9.5 days) [63]. Two German studies assessed the effect of PCT guidance in surgical ICU patients with suspected bacterial infections in the post-operative course [64,65]. PCT guidance resulted in a significant reduction of antibiotic therapy and similar medical outcomes. In addition, the length of intensive care treatment in the PCT-guided group was significantly shorter than that in the control group (15.5 versus 17.7 days), a finding similar to the first ICU study [61]. Importantly, the use of PCT for discontinuation of antibiotics in ICU patients is still limited by a relatively small number of patients included in previous trials and awaits further large-scale validation. There are currently different ongoing trials focusing on this vulnerable patient population that should shed further light on the benefits and harms of PCT use in ICU patients.

\section{Limitations and areas of uncertainty}

Sepsis is not a well-defined disease, but a consequence of different infectious disease entities and far too complex to be reduced to a single cut-off of any surrogate marker. Limitations of every PCT measurement include false-positive and false-negative results [8,11]. Different pathogens might induce distinct responses resulting in a variable up-regulation of circulating PCT levels [66]. While highly elevated PCT levels were found in patients with pneumococcal CAP [14], the same was not true in CAP due to atypical organisms such as mycoplasma [66]. Antimicrobial pre-treatment may influence the level of PCT resulting in lower PCT levels [67], although it remains unclear whether this relates to a direct effect or rather to lower microbial burden in patients treated with antibiotics. Unspecific elevations of PCT levels in the absence of a bacterial infection can typically be seen in situations of massive stress, for example after severe trauma and surgery $[8,68-70]$ or in patients after cardiac shock [71]. Although the available evidence from intervention studies favors the use of PCT for de-escalation of antibiotic therapy, the same may not be true for escalation of antibiotics when PCT increases as recently demonstrated [72]. In this study PCT-guided escalation of diagnostic procedures and antibiotic therapy in the ICU did not improve survival and led to worse secondary outcomes in patients.

\section{Summary, future directions and conclusions}

For upper and lower respiratory tract infection in ICU patients with sepsis and post-operative infections, randomized-controlled studies have shown the efficacy of using PCT algorithms to guide antibiotic decisions. For other types of infections, only observational studies are available which are importantly limited by the lack of a true gold standard. Most intervention studies were conducted in European countries including Switzerland, Germany, France and Denmark (and two in China) and validation in other countries and continents is therefore warranted. Importantly, PCT levels must always be evaluated in the context of a careful clinical and microbiological assessment. As the kinetics of PCT are of particular diagnostic and prognostic interest, repeated measurements should be performed if feasible, especially in persistently sick patients if antibiotics are withheld. The limitations of every PCT measurement include false-positive and false-negative results [8]. Unspecific elevations of PCT levels in the absence of a bacterial infection can typically be seen in situations of massive cell death, for example after severe trauma or surgery $[8,68,69]$. In these situations, PCT values are usually only moderately elevated and show a rapid decline in follow-up measurements. Conversely, falsely low PCT levels, typically seen during the early course or localized state of an infection, often show an increase in the follow-up measurements. Therefore, highly sensitive PCT assays are required, as subtle changes of $\mathrm{PCT}$ at very low concentrations can be monitored, increasing the sensitivity of the test and thus the safety of patients.

Emerging bacterial resistance to antimicrobial agents calls for more effective efforts to reduce the unnecessary 
and prolonged use of antibiotics in self-limiting nonbacterial and resolving diseases [1]. Patients and physicians share a common goal of improving symptoms from infection as fast as possible and often see antibiotics as the most expeditious intervention to achieve it. This one-size fits-all approach fails to consider the basic questions of who benefits from antibiotic therapy, and if treated, what would be the optimal duration. Using PCT, which mirrors the likelihood of bacterial infection and the severity of infection, to guide antibiotic therapy, is a persuasive, evidence-based approach to a more rational use of antibiotics.

\section{List of abbreviations}

AB: antibiotic; CAP: community-acquired pneumonia; CRP: C-reactive protein; ECOPD: exacerbation of chronic obstructive pulmonary disease; ED: Emergency department: ICU: intensive care unit: IFN: interferon; IL: interleukin; LPS: lipopolysaccharide; PCT: procalcitonin; TNF: tumor necrosis factor; RCT: randomised-controlled trial; UTI: urinary tract infection; WBC white blood cells.

\section{Author details}

'Harvard School of Public Health, 667 Huntington Ave, 02115 Boston (MA), USA. ${ }^{2}$ University Department of Medicine, Kantonsspital Aarau, Tellstrasse, CH-5001 Aarau, Switzerland.

\section{Authors' contributions}

PS drafted the initial manuscript. WCA and BM commented on the manuscript. All authors approved the final version.

\section{Competing interests}

Drs Schuetz, Albrich, and Mueller reported receiving support from BRAHMS Inc and Biomerieux to attend meetings and fulfill speaking engagements. Dr Mueller reported serving as a consultant and receiving research support from BRAHMS and BioMérieux Inc.

Received: 4 May 2011 Accepted: 22 September 2011

Published: 22 September 2011

\section{References}

1. Whitney CG, Farley MM, Hadler J, Harrison LH, Lexau C, Reingold A, Lefkowitz L, Cieslak PR, Cetron M, Zell ER, Jorgensen JH, Schuchat A, Active Bacterial Core Surveillance Program of the Emerging Infections Program Network: Increasing prevalence of multidrug-resistant Streptococcus pneumoniae in the United States. N Engl J Med 2000, 343:1917-1924.

2. Roberts Rebecca R, Hota B, Ahmad I, Scott li RD, Foster Susan D, Abbasi F, Schabowski S, Kampe Linda M, Ciavarella Ginevra G, Supino M, Naples J, Cordell R, Levy SB, Weinstein RA: Hospital and Societal Costs of Antimicrobial-Resistant Infections in a Chicago Teaching Hospital: Implications for Antibiotic Stewardship. Clin Infect Dis 2009, 49:1175-1184.

3. Ohl CA, Luther VP: Antimicrobial stewardship for inpatient facilities. J Hosp Med 2011, 6(Suppl 1):S4-15.

4. Lee TH, Goldman L: Evaluation of the patient with acute chest pain. $N$ Engl J Med 2000, 342:1187-1195.

5. Agnelli G, Becattini C: Acute pulmonary embolism. N Engl J Med 2010, 363:266-274.

6. Muller B, Harbarth S, Stolz D, Bingisser R, Mueller C, Leuppi J, Nusbaumer C, Tamm M, Christ-Crain M: Diagnostic and prognostic accuracy of clinical and laboratory parameters in community-acquired pneumonia. BMC Infect Dis 2007, 7:10.

7. Gogos CA, Drosou E, Bassaris HP, Skoutelis A: Pro- versus antiinflammatory cytokine profile in patients with severe sepsis: a marker for prognosis and future therapeutic options. J Infect Dis 2000, 181:176-180

8. Christ-Crain M, Muller B: Procalcitonin in bacterial infections-hype, hope, more or less? Swiss Med Wkly 2005, 135:451-460.
9. Christ-Crain M, Muller B: Biomarkers in respiratory tract infections: diagnostic guides to antibiotic prescription, prognostic markers and mediators. Eur Respir J 2007, 30:556-573.

10. Linscheid P, Seboek D, Zulewski H, Keller U, Muller B: Autocrine/paracrine role of inflammation-mediated calcitonin gene-related peptide and adrenomedullin expression in human adipose tissue. Endocrinology 2005, 146:2699-2708

11. Schuetz P, Christ-Crain M, Muller B: Procalcitonin and other biomarkers to improve assessment and antibiotic stewardship in infections-hope for hype? Swiss Med Wkly 2009, 139:318-326.

12. Becker KL: Procalcitonin and the Calcitonin Gene Family of Peptides in Inflammation, Infection, and Sepsis: A Journey from Calcitonin Back to Its Precursors. J Clin Endocrinol Metab 2004, 89:1512-1525.

13. Schuetz $P$, Mueller B, Trampuz A: Serum procalcitonin for discrimination of blood contamination from bloodstream infection due to coagulasenegative staphylococci. Infection 2007, 35:352-355.

14. Muller F, Christ-Crain M, Bregenzer T, Krause M, Zimmerli W, Mueller B, Schuetz P: Procalcitonin levels predict bacteremia in patients with community-acquired pneumonia: a prospective cohort trial. Chest 2010, 138:121-129.

15. van Nieuwkoop C, Bonten TN, van't Wout JW, Kuijper EJ, Groeneveld GH, Becker MJ, Koster T, Wattel-Louis GH, Delfos NM, Ablij HC, Leyten EM, van Dissel JT: Procalcitonin reflects bacteremia and bacterial load in urosepsis syndrome: a prospective observational study. Crit Care 2010, 14:R206

16. Christ-Crain M, Stolz D, Bingisser R, Muller C, Miedinger D, Huber PR, Zimmerli W, Harbarth S, Tamm M, Muller B: Procalcitonin guidance of antibiotic therapy in community-acquired pneumonia: a randomized trial. Am J Respir Crit Care Med 2006, 174:84-93.

17. Schuetz P, Christ-Crain M, Albrich W, Zimmerli W, Mueller B: Guidance of antibiotic therapy with procalcitonin in lower respiratory tract infections: insights into the ProHOSP study. Virulence 2010, 1:88-92.

18. Schuetz P, Suter-Widmer I, Chaudri A, Christ-Crain M, Zimmerli W, Mueller B: Prognostic value of procalcitonin in community-acquired pneumonia. Eur Resp J 2011, 37:384-392

19. Kruger S, Ewig S, Marre R, Papassotiriou J, Richter K, von Baum H, Suttorp N Welte T: Procalcitonin predicts patients at low risk of death from community-acquired pneumonia across all CRB-65 classes. Eur Respir $J$ 2008, 31:349-355.

20. Huang D, Weissfeld L, Kellum J, Yealy D, Kong L, Martino M, Angus D: Risk Prediction With Procalcitonin and Clinical Rules in Community-Acquired Pneumonia. Ann Emerg Med 2008, 52:48-58.e2.

21. Haeuptle J, Zaborsky R, Fiumefreddo R, Trampuz A, Steffen I, Frei R, ChristCrain M, Muller B, Schuetz P: Prognostic value of procalcitonin in Legionella pneumonia. Eur J Clin Microbiol Infect Dis 2009, 28:55-60.

22. Jensen JU, Heslet L, Jensen TH, Espersen K, Steffensen P, Tvede M: Procalcitonin increase in early identification of critically ill patients at high risk of mortality. Crit Care Med 2006, 34:2596-2602.

23. Schuetz P, Albrich W, Christ-Crain M, Chastre J, Mueller B: Procalcitonin for guidance of antibiotic therapy. Expert Rev Anti Infect Ther 2010, 8:575-587.

24. Nylen ES, Muller B, Becker KL, Snyder RH: The future diagnostic role of procalcitonin levels: the need for improved sensitivity. Clin Infect Dis 2003, 36:823-824

25. Steinbach G, Rau B, Debard AL, Javourez JF, Bienvenu J, Ponzio A, Bonfa A, Hubl W, Demant T, Kulpmann WR, Buchholz J, Schumann G: Multicenter evaluation of a new immunoassay for procalcitonin measurement on the Kryptor System. Clin Chem Lab Med 2004, 42:440-449.

26. Pecile P, Miorin E, Romanello C, Falleti E, Valent F, Giacomuzzi F, Tenore A: Procalcitonin: a marker of severity of acute pyelonephritis among children. Pediatrics 2004, 114:e249-254.

27. Knudsen JB, Fuursted K, Petersen E, Wierup P, Molgaard H, Poulsen SH, Egeblad H: Procalcitonin in 759 patients clinically suspected of infective endocarditis. Am J Med 2010, 123:1121-1127.

28. Mueller C, Huber R, Laifer G, Mueller B, Buerkle G, Perruchoud AP: Procalcitonin and the early diagnosis of infective endocarditis. Circulation 2004, 109:1707-1710

29. Kafetzis DA, Velissariou IM, Nikolaides P, Sklavos M, Maktabi M, Spyridis G, Kafetzis DD, Androulakakis E: Procalcitonin as a predictor of severe appendicitis in children. Eur J Clin Microbiol Infect Dis 24:484-487.

30. Sand M, Trullen XV, Bechara FG, Pala XF, Sand D, Landgrafe G, Mann B: A prospective bicenter study investigating the diagnostic value of 
procalcitonin in patients with acute appendicitis. Eur Surg Res 2009, 43:291-297.

31. Anielski R, Kusnierz-Cabala B, Szafraniec K: An evaluation of the utility of additional tests in the preoperative diagnostics of acute appendicitis. Langenbecks Arch Surg 2010, 395:1061-1068.

32. Markogiannakis H, Memos N, Messaris E, Dardamanis D, Larentzakis A, Papanikolaou D, Zografos GC: Manouras: Predictive value of procalcitonin for bowel ischemia and necrosis in bowel obstruction. Surgery 2011, 149:394-403.

33. Gurda-Duda A, Kusnierz-Cabala B, Nowak W, Naskalski JW, Kulig J: Assessment of the prognostic value of certain acute-phase proteins and procalcitonin in the prognosis of acute pancreatitis. Pancreas 2008, 37:449-453.

34. Brunkhorst FM, Eberhard OK, Brunkhorst R: Early identification of biliary pancreatitis with procalcitonin. Am J Gastroenterol 1998, 93:1191-1192.

35. Bihari D: Monitoring procalcitonin is of value in acute pancreatitis. BMJ 2004, 329:232.

36. Mofidi R, Suttie SA, Patil PV, Ogston S, Parks RW: The value of procalcitonin at predicting the severity of acute pancreatitis and development of infected pancreatic necrosis: systematic review. Surgery 2009, 146:72-81.

37. Hugle T, Schuetz P, Mueller B, Laifer G, Tyndall A, Regenass S, Daikeler T: Serum procalcitonin for discrimination between septic and non-septic arthritis. Clin Exp Rheumatol 2008, 26:453-456.

38. Butbul-Aviel Y, Koren A, Halevy R, Sakran W: Procalcitonin as a diagnostic aid in osteomyelitis and septic arthritis. Pediatr Emerg Care 2005, 21:828-832.

39. Stryjewski GR, Nylen ES, Bell MJ, Snider RH, Becker KL, Wu A, Lawlor C, Dalton H: Interleukin-6, interleukin-8, and a rapid and sensitive assay for calcitonin precursors for the determination of bacterial sepsis in febrile neutropenic children. Pediat Crit Care Med 2005, 6:129-135

40. Sakr Y, Sponholz C, Tuche F, Brunkhorst F, Reinhart K: The role of procalcitonin in febrile neutropenic patients: review of the literature. Infection 2008, 36:396-407.

41. Koivula I, S HMLI, Jantunen E, Pulkki K, Kuittinen T, Nousiainen T, Juutilainen A: Elevated procalcitonin predicts Gram-negative sepsis in haematological patients with febrile neutropenia. Scand J Infect Dis 2011 , 43:471-478.

42. Muller B, Peri G, Doni A, Perruchoud AP, Landmann R, Pasqualini F, Mantovani A: High circulating levels of the IL-1 type II decoy receptor in critically ill patients with sepsis: association of high decoy receptor levels with glucocorticoid administration. J Leukoc Biol 2002, 72:643-649.

43. de Kruif MD, Lemaire LC, Giebelen IA, Struck J, Morgenthaler NG, Papassotiriou J, Elliott PJ, van der Poll T: The influence of corticosteroids on the release of novel biomarkers in human endotoxemia. Intensive Care Med 2008, 34:518-522

44. Timper K, Grisouard J, Radimerski T, Dembinski K, Peterli R, Haring A Frey DM, Zulewski H, Keller U, Muller B, Christ-Crain M: Glucosedependent insulinotropic polypeptide (GIP) induces calcitonin generelated peptide (CGRP)-I and procalcitonin (Pro-CT) production in human adipocytes. J Clin Endocrinol Metab 2011, 96:E297-303.

45. Radimerski TM, Grisouard J, Timper K, Zulewski H, Christ-Crain M, Keller U, Muller B: Role of calcium in lipopolysaccharide-induced calcitonin gene expression in human adipocytes. Innate Immun 2010

46. Linscheid P: In Vitro and in Vivo Calcitonin I Gene Expression in Parenchymal Cells: A Novel Product of Human Adipose Tissue. Endocrinology 2003, 144:5578-5584.

47. Schuetz P, Christ-Crain M, Huber AR, Muller B: Long-term stability of procalcitonin in frozen samples and comparison of Kryptor and VIDAS automated immunoassays. Clin Biochem 2010, 43:341-344.

48. Hubl W, Krassler J, Zingler C, Pertschy A, Hentschel J, Gerhards-Reich C, Mack M, Demant T: Evaluation of a fully automated procalcitonin chemiluminescence immunoassay. Clin Lab 2003, 49:319-327.

49. de Wolf HK, Gunnewiek JK, Berk Y, van den Ouweland J, de Metz M: Comparison of a new procalcitonin assay from roche with the established method on the brahms kryptor. Clin Chem 2009, 55:1043-1044.

50. Christ-Crain M, Jaccard-Stolz D, Bingisser R, Gencay MM, Huber PR Tamm M, Muller B: Effect of procalcitonin-guided treatment on antibiotic use and outcome in lower respiratory tract infections: clusterrandomised, single-blinded intervention trial. Lancet 2004, 363:600-607.
51. Stolz D, Christ-Crain M, Bingisser R, Leuppi J, Miedinger D, Muller C, Huber P, Muller B, Tamm M: Antibiotic treatment of exacerbations of COPD: a randomized, controlled trial comparing procalcitonin-guidance with standard therapy. Chest 2007, 131:9-19.

52. Schuetz $\mathrm{P}$, Christ-Crain M, Thomann R, Falconnier C, Wolbers M, Widmer I, Neidert S, Fricker T, Blum C, Schild U, Regez K, Schoenenberger R, Henzen C, Bregenzer T, Hoess C, Krause M, Bucher HC, Zimmerli W, Mueller B, ProHOSP Study Group: Effect of procalcitonin-based guidelines vs standard guidelines on antibiotic use in lower respiratory tract infections: the ProHOSP randomized controlled trial. JAMA 2009, 302:1059-1066.

53. Kristoffersen KB, Sogaard OS, Wejse C, Black FT, Greve T, Tarp B, Storgaard M, Sodemann M: Antibiotic treatment interruption of suspected lower respiratory tract infections based on a single procalcitonin measurement at hospital admission-a randomized trial. Clin Microbiol Infect 2009, 15:481-487.

54. Long W, Deng XQ, Tang JG, Xie J, Zhang YC, Zhang Y, Gao YY, Lu G: [The value of serum procalcitonin in treatment of community acquired pneumonia in outpatient]. Zhonghua Nei Ke Za Zhi 2009, 48:216-219.

55. Long W, Deng X, Zhang Y, Lu G, Xie J, Tang J: Procalcitonin-guidance for reduction of antibiotic use in low-risk outpatients with community acquired pneumonia. Respirology 2011, 16:819-824.

56. Schuetz P, Batschwaroff M, Dusemund F, Albrich W, Burgi U, Maurer M, Brutsche M, Huber AR, Muller B: Effectiveness of a procalcitonin algorithm to guide antibiotic therapy in respiratory tract infections outside of study conditions: a post-study survey. Eur J Clin Microbiol Infect Dis 2010, 29:269-277.

57. Evans AT, Husain S, Durairaj L, Sadowski LS, Charles-Damte M, Wang Y: Azithromycin for acute bronchitis: a randomised, double-blind, controlled trial. Lancet 2002, 359:1648-1654

58. Burkhardt O, Ewig S, Haagen U, Giersdorf S, Hartmann O, Wegscheider K, Hummers-Pradier E, Welte T: Procalcitonin guidance and reduction of antibiotic use in acute respiratory tract infection. Eur Respir J 2010, 36:601-607.

59. Briel M, Christ-Crain M, Young J, Schuetz P, Huber P, Periat P, Bucher HC, Muller B: Procalcitonin-guided antibiotic use versus a standard approach for acute respiratory tract infections in primary care: study protocol for a randomised controlled trial and baseline characteristics of participating general practitioners [ISRCTN73182671]. BMC Fam Pract 2005, 6:34

60. Briel M, Schuetz P, Mueller B, Young J, Schild U, Nusbaumer C, Periat P, Bucher HC, Christ-Crain M: Procalcitonin-guided antibiotic use vs a standard approach for acute respiratory tract infections in primary care. Arch Intern Med 2008, 168:2000-2007, discussion 2007-2008.

61. Nobre V, Harbarth S, Graf JD, Rohner P, Pugin J: Use of procalcitonin to shorten antibiotic treatment duration in septic patients: a randomized trial. Am J Respir Crit Care Med 2008, 177:498-505.

62. Bouadma L, Luyt CE, Tubach F, Cracco C, Alvarez A, Schwebel C, Schortgen F, Lasocki S, Veber B, Dehoux M, Bernard M, Pasquet B, Régnier B, Brun-Buisson C, Chastre J, Wolff M, PRORATA trial group: Use of procalcitonin to reduce patients' exposure to antibiotics in intensive care units (PRORATA trial): a multicentre randomised controlled trial. Lancet 2010, 375:463-474

63. Stolz D, Smyrnios N, Eggimann P, Pargger H, Thakkar N, Siegemund M, Marsch S, Azzola A, Rakic J, Mueller B, Timm M: Procalcitonin for reduced antibiotic exposure in ventilator-associated pneumonia: a randomised study. Eur Respir J 2009, 34:1364-1375.

64. Hochreiter M, Köhler T, Schweiger A, Keck F, Bein B, von Spiegel T, Schroeder S: Procalcitonin to guide duration of antibiotic therapy in intensive care patients: a randomized prospective controlled trial. Critical Care 2009, 13:R83

65. Schroeder S, Hochreiter M, Koehler T, Schweiger AM, Bein B, Keck FS, von Spiegel T: Procalcitonin (PCT)-guided algorithm reduces length of antibiotic treatment in surgical intensive care patients with severe sepsis: results of a prospective randomized study. Langenbecks Arch Surg 2009, 394:221-226

66. Kruger S, Ewig S, Papassotiriou J, Kunde J, Marre R, von Baum H, Suttor N, Welte T: Inflammatory parameters predict etiologic patterns but do not allow for individual prediction of etiology in patients with CAP: results from the German competence network CAPNETZ. Respir Res 2009, 10:65.

67. Kruger S, Ewig S, Kunde J, Hartmann O, Marre R, Suttorp N, Welte T: Assessment of inflammatory markers in patients with community- 
acquired pneumonia-influence of antimicrobial pre-treatment: results from the German competence network CAPNETZ. Clin Chim Acta 2010, 411:1929-1934.

68. Uzzan B, Cohen R, Nicolas P, Cucherat M, Perret GY: Procalcitonin as a diagnostic test for sepsis in critically ill adults and after surgery or trauma: a systematic review and meta-analysis. Crit Care Med 2006, 34:1996-2003.

69. Hunziker S, Hugle T, Schuchardt K, Groeschl I, Schuetz P, Mueller B, Dick W, Eriksson U, Trampuz A: The value of serum procalcitonin level for differentiation of infectious from noninfectious causes of fever after orthopaedic surgery. J Bone Joint Surg Am 92:138-148.

70. Sponholz C, Sakr Y, Reinhart K, Brunkhorst F: Diagnostic value and prognostic implications of serum procalcitonin after cardiac surgery: a systematic review of the literature. Crit Care 2006, 10(5):R145.

71. Schuetz P, Affolter B, Hunziker S, Winterhalder C, Fischer M, Balestra GM, Hunziker $P$, Marsch S: Serum procalcitonin, C-reactive protein and white blood cell levels following hypothermia after cardiac arrest: a retrospective cohort study. Eur J Clin Invest 2010, 40:376-381.

72. Jensen $J U$, Hein L, Lundgren B, Bestle MH, Mohr $\Pi$, Andersen $M H$, Thornberg KJ, Loken J, Steensen M, Fox Z, Tousi H, Søe-Jensen P, Lauritsen AO, Strange D, Petersen PL, Reiter N, Hestad S, Thormar K, Fjeldborg P, Larsen KM, Drenck NE, Ostergaard C, Kjær J, Grarup J, Lundgren JD, for the The Procalcitonin And Survival Study (PASS) Study Group: Procalcitonin-guided interventions against infections to increase early appropriate antibiotics and improve survival in the intensive care unit: A randomized trial. Crit Care Med 2011.

73. Martinot $M$, Sordet $C$, Soubrier $M$, Puechal $X$, Saraux A, Liote F, Guggenbuhl P, Legre V, Jaulhac B, Maillefert JF, Zeisel M, Coumaros G, Sibilia J: Diagnostic value of serum and synovial procalcitonin in acute arthritis: a prospective study of 42 patients. Clin Exp Rheumatol 2005, 23:303-310.

74. Riedel S, Melendez JH, An AT, Rosenbaum JE, Zenilman JM: Procalcitonin as a marker for the detection of bacteremia and sepsis in the emergency department. Am J Clin Pathol 2011, 135:182-189.

75. Gendrel D, Raymond J, Assicot M, Moulin F, Iniguez JL, Lebon P, Bohuon C: Measurement of procalcitonin levels in children with bacterial or viral meningitis. Clin Infect Dis 1997, 24:1240-1242.

76. Marc E, Menager C, Moulin F, Stos B, Chalumeau M, Guerin S, Lebon P, Brunet F, Raymond J, Gendrel D: [Procalcitonin and viral meningitis: reduction of unnecessary antibiotics by measurement during an outbreak]. Arch Pediatr 2002, 9:358-364.

77. Mary R, Veinberg F, Couderc R: [Acute meningitidis, acute phase proteins and procalcitonin]. Ann Biol Clin 2003, 61:127-137.

78. Hunziker S, Hugle T, Schuchardt K, Groeschl I, Schuetz P, Mueller B, Dick W, Eriksson U, Trampuz A: The value of serum procalcitonin level for differentiation of infectious from noninfectious causes of fever after orthopaedic surgery. J Bone Joint Surg Am 2010, 92:138-148.

\section{Pre-publication history}

The pre-publication history for this paper can be accessed here: http://www.biomedcentral.com/1741-7015/9/107/prepub

doi:10.1186/1741-7015-9-107

Cite this article as: Schuetz et al:: Procalcitonin for diagnosis of infection and guide to antibiotic decisions: past, present and future. BMC

Medicine 2011 9:107.

\section{Submit your next manuscript to BioMed Central and take full advantage of:}

- Convenient online submission

- Thorough peer review

- No space constraints or color figure charges

- Immediate publication on acceptance

- Inclusion in PubMed, CAS, Scopus and Google Scholar

- Research which is freely available for redistribution 